\title{
総合健診（人間ドック健診）における 脂質異常症診療
}

岸本 憲明1）西㟝 泰弘 ${ }^{11}$

\section{抄 録}

脂質異常症は健康診断で遭遇する機会がもつとも多い代表的疾患であると共に、動脈硬化性疾患発症の明らか なリスク因子の1つでもある。実際の健診現場では総コレステロール、トリグリセリド（TG）、高比重リポ蛋白 (HDL-C)、低比重リポ蛋白（LDL-C）などが測定され、日本動脈硬化学会診断基準により診断および重症度が 評価される。とりわけ LDL-C 評価方法について従来の Friedewald 式計算法と直接測定法が混乱していたが、 近年の LDL-C 試薬改良により、現在は直接測定法による評価代用も可能であると、動脈硬化性疾患予防ガイド ライン2017年版では示された。

一方、非常に冠動脈疾患発症リスクの高(家族性高コレステロール血症（FH）の本邦における診断率は極め て低い。総合健診や人間ドックの場はFHスクリーニングを行う上では有用な機会である。専門診療科への受診 勧奨につなげるためにも、同ガイドラインに則り、LDL-C180mg/dL 以上の受診者に対しては当日結果説明時 に必要な問診の再聴取と触診によるアキレス腱肥厚の有無確認を積極的に啓蒙すべきと考える。

(総合健診. $2019 ; 46: 236-239$.)

キーワード＼cjkstart脂質異常症、低比重リポ蛋白コレステロール、低比重リポ蛋白コレステロール直接測定法、家 族性高コレステロール血症、アキレス腱触診

\section{ヤ・はじめに}

厚生労働省の「平成26年患者調査の概況」による と脂質異常症の患者数は約 206 万人（男性59万 6,000 人、女性 146 万 5,000 人) であり、その数は年々増え ている (平成 8 年は約 96 万人) ${ }^{1)}$ 。さらに、脂質異常 症は加齢に伴って増加する（30～39歳5.8\%，40～ 49 歳 $10.7 \% ， 50 ５ 9$ 歳 $17.7 \% ， 60 ６ 9$ 歳26.8\%，70 歳以上 $35.0 \%$; 平成 26 年 $)^{2)}$ 。脂質異常症は虚血性心 疾患や脳血管疾患などの動脈硬化性疾患の主要な発 症リスクの 1 つであり、急速に高齢化が進むなか、 早期に診断し、総合健診受診者の動脈硬化性包括的 リスクを把握した上で、適切な保健指導や受診勧奨 につなげることが重要である。本稿では脂質異常症 の臨床検查学的診断の現況と問題点、動脈硬化性疾 患発症リスクの非常に高い家族性高コレステロール 血症を総合健診で見つけるために留意すべきポイン 卜を解説する。

1 ) 東海大学医学部基盤診療学系健康管理学

\section{\脂質異常症の臨床検査学的診断の現況}

脂質異常症は空腹時採血により施行され、スク リーニングのための基本的な検査項目は、総コレステ ロール（TC）、トリグリセライド（TG）、高比重リポ 蛋白（HDL-C）およびnon-HDL-Cの 4 項目である。 原則的に 10 時間以上絶食後の空腹時に採血するが、 動脈硬化性疾患予防ガイドライン 2012年版3) では空 腹時 TGが $400 \mathrm{mg} / \mathrm{dL}$ 未満の場合、低比重リポタン パク（LDL-C）の評価には原則として Friedewald の式（F 式：LDL-C = TC-HDL-C-TG/5）を用い

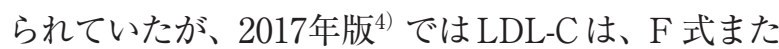
は直接測定法で評価することに変更された。

LDL-C 直接測定法にこれまでに保険診療制度や試 薬精度などによる問題が診療を行う上で障害となっ ていた経緯がある。1997年本邦において世界で初め て血清から直接 LDL-C を測定できる試薬が開発さ れた。以後本邦では LDL-C は直接測定法により診 療や総合健診、人間ドックなど多くの臨床の現場で 評価されるようになった。正常健常者に打ける測定 では概ね問題なく評価されていたが、Miller らの報 
告をはじめ、明らかなリポ蛋白異常を有する群にお いては精確性に問題がみられた において精查したところ、正常健常者の LDL-C は 誤算範囲内で測定できていたが、リポ蛋白異常症例 群では、高 TG 血症で比較的、低 LDL-C 血症では プラスバイアスを認めた ${ }^{7)} 。 2017$ 年に発表された各 試薬改良後の検証論文では、4 社の試薬は空腹時お よび非空腹時、正常健常者およびリポ蛋白異常症例 問わず精確度が保たれていることが報告された ${ }^{8,9)}$ 。

動脈硬化性疾患予防ガイドライン 2012 年版および 2017年版では、TG が $400 \mathrm{mg} / \mathrm{dL}$ 以上あるいは食後 採血評価では non-HDL-Cによる評価推奨されてい るため、HDL-C 直接測定法の精確度も重要である。 LDL-C と同様に HDL-C 試薬の調査も行われ、正常 健常者の HDL-C は本邦で使用されている試薬はい ずれも誤差範囲内での測定であったが、リポ蛋白異 常症例では2-3の試薬を除き、基準を満たしている ことが確認された ${ }^{10)}$ 。また、先の 4 社の試薬検討で は正常健常者、リポ蛋白異常症例にかかわらず、空 腹時および非空腹時のいずれも精確度が保たれてい た8)。これまでに non-HDL-C は LDL-Cに+30mg/ dLが目安とされていたが、高 TG 血症を伴わない場 合は LDL-C との差が $30 \mathrm{mg} / \mathrm{dL}$ 以下になる可能性を 念頭に置く必要がある。

\section{家族性高コレステロール血症の 臨床病態像}

家族性高コレステロール血症 (FH) は (1)高 LDL-C 血症、(2)早発性冠動脈疾患、(3)腱 - 皮虐黄色 腫を 3 主徵とする常染色体性遺伝性疾患である。 FH 患者では生下時から高 LDL-C 血症が持続し、へ テロ接合体型 $\mathrm{FH}$ 症例では未治療の男性30-50歳、 女性50-70歳で心筋梗塞や狭心症などの虚血性心疾 患を発症することが多い11)。疫学的に FH の頻度は 日本でも諸外国でも同じであり、へテロ接合体型 FH は200-500人に 1 人、ホモ接合体型 FH は 100 万 人に 1 人といわれている。しかしながら本邦での $\mathrm{FH}$ の診断率は $1 \%$ 以下で諸外国と比較しても非常 に低值である ${ }^{12)}$ 。

\section{ヤ 家族性高コレステロール血症の診断}

総合健診や人間ドック健診、特定健康診查などの 各種健診でみられる FH はへテロ接合体型と思われ る。成人型（15歳以上） FHへテロ接合体の診断基
準に準拠すると、甲状腺機能低下症やネフローゼ症 候群などの続発性高脂血症を除外したうえで、(1)高 LDL-C 血症（未治療時 LDL-C180mg/dL 以上)、(2) 腱黄色腫 (手背、肘、膝などまたはアキレス腱肥 厚 ; X 線撮影 ${ }^{14)}$ により $9 \mathrm{~mm}$ 以上で診断）あるいは 皮膚結節性黄色腫、(3) FH あるいは早発性冠動脈疾 患の家族歴 ( 2 親等以内, 男性55歳未満, 女性65歳 未満）のうち 2 項目以上の該当する場合 $\mathrm{FH}$ と診断 する13)。

\section{ヤリアキレス腱撮影方法}

\section{撮影体位}

座位㧍よび側臥位で受光面に下腿部と足関節外果 側を付け、下腿と足底 90 度となるようにする。足関 節の進展、屈曲、内旋、外旋は、アキレス腱肥厚測 定值に影響をおよぼすため、なるべく撮影補助具な どを使用し撮影体位の再現性精度向上に努める。

\section{撮影条件}

デジタルシステムを使用時は $50 \mathrm{kV} 、 5.0 \mathrm{mAs}$ (例え ば、 $100 \mathrm{~mA} \times 0.05$ 秒、 $50 \mathrm{~mA} \times 0.1$ 秒 $)$ とする。 $\mathrm{mAs}$ 值に関しては必要に応じて増減する。

\section{撮影距離 (X 線管焦点から X 線受光面距離)}

$\mathrm{X}$ 線画像上での拡大率の影響をなるべく排除する ことを考慮し、 $120 \mathrm{~cm}$ とする。可能であれば、拡大 率を補正するために、撮影時アキレス腱と同じ高さ に鉛スケールなど（サイズが既知の X 線非透過性の もの) を置き撮影を行う。

\section{X 線中心線}

受光面に対して垂直に脛骨内果の後縁に入射す る。

\section{画像処理条件}

デジタル X 線画像システムによる評価の場合、ア キレス腱、脂肪組織、皮膚が明暸に描出可能な処理 条件を推奖する。

\section{アキレス腱肥厚測定}

画像参照端末で測定する場合は、計測ツールを使 用し、アキレス腱最大肥厚部を測定する。フィルム 上での測定の場合は、当倍出力を行いノギスや定規 を使用して肥厚測定を行う。計測の精度の向上を目 的とした計測ソフト開発が望まれる。

\section{総合健診における $\mathrm{FH}$}

スクリーニングポイント

脂質異常症自体は自覚症状がないことが多いた 
め、健診現場では問診や診察が重要となる。しかし ながら、実際の健診の場では受診者数が多く全例に 同じレベルでスクリーニングを行うことは困難であ る。そのため少なくとも以前から脂質異常症の既往 者や当該健診で脂質異常症を指摘されたケースに は、結果説明時にでも、(1)過去の脂質異常症の有 無、(2)脂質異常症の家族歴、(3)冠動脈疾患や突然死 などの家族歴の聴取を再度行う。また、身体所見と して最も重要な徵候はアキレス腱肥厚である。アキ レス腱反射を行うようにアキレス腱を若干進展され てつまむように触診し、厚くて硬いアキレス腱が触 知した場合 $\mathrm{FH}$ を強く疑う。国立循環器病センター の報告 ${ }^{15)}$ では X 線上のアキレス腱肥厚は感度が $64.1 \%$ 、特異度 $98.6 \%$ と、その有用性が示されてい ることからも理学的所見としてのアキレス腱触診が 大変重要と考える。その他眼瞼黄色腫や角膜輪が参 考となる。眼瞼黄色腫はへテロ接合体型 $\mathrm{FH}$ の $50 \%$ でみられるものの健常者にも認めるため診断上の特 異性は低い16)。そのため診断基準には含まれずに参 考所見である。角膜輪は高齢者でみられる老人環と 違い、形状がシャープであること多く、若年者でみ られた場合には診断価值が高い。

\section{\総合健診における \\ $\mathrm{FH}$ スクリーニングの今後の展望}

2015年の人間ドック協会報告では、60歳以上の人 間ドック健診受診者で胃癌の発見率は $0.183 \%$ 、大 腸癌では $0.102 \%$ あ゙った。これは $500 １, 000$ 人に 1 人を検出したことになる。前述の如く、200-500 人に 1 人の頻度で発症するへテロ接合体型 $\mathrm{FH}$ は脂 質異常症の中でも非常に動脈硬化性疾患発症のリス クが高く、可及的早期からの冠動脈疾患発症予防が 必要とされる。様々な健診の場を通じて、本邦にお ける FH スクリーニング、 FH 診断率の向上するこ とにより多くの動脈硬化性疾患を未然に防ぐことが でき、医療経済の側面からも極めてメリットが大き い。そのためには、当該健診時に LDL-C180mg/dL 以上の受診者については、結果説明時に必要な問診 の再聴取、侵襲がなく数秒で終わるアキレス腱触診 を積極的に行い、そして本学会としても日本動脈硬 化学会と連携して啓蒙することが重要である。FH が強く疑われた際には可及的速やかに専門診療科へ の受診勧奨を強く促してもらいたい。
著者の COI（conflict of interest）開示 : 本論文発表内容 に関連して特に申告なし

\section{$\longrightarrow$ 参考文献}

1 ）厚生労働省大臣官房統計情報部 : 平成26年（2014）患 者調査の概況. 東京, 厚生労働省, 2016. (オンライン) 入手先〈https://www.mhlw.go.jp/toukei/saikin/hw/ kanja/14/dl/01.pdf , （参照2018-12-25）

2 ) 厚生労働省健康局：平成26年国民健康 - 栄養調査報 告. 東京, 厚生労働省, 2016. (オンライン) 入手先 〈https://www.mhlw.go.jp/bunya/kenkou/eiyou/dl/ h26-houkoku.pdf $\rangle$, (参照2018-12-25)

3 ）日本動脈硬化学会 : 動脈硬化性疾患予防ガイドライン 2012年版, 東京, 協和企画, 2012.

4) 日本動脈硬化学会 : 第 1 章 本ガイドラインの要約. 動 脈硬化性疾患予防ガイドライン 2017 年版, 東京, 協和企 画, 2017; 13-4.

5 ) Miller WG, Myers GL, Sakurabayashi I, et al: Seven direct methods for measuring HDL and LDL cholesterol compared with ultracentrifugation reference measurement procedures. Clin Chem 2010; 56: 977-86.

6 ) Kurosawa H, Yoshida H, Yanai H, et al: Comparative study between anion-exchange HPLC and homogeneous assay methods in regard to the accuracy of high- and low-density lipoprotein cholesterol measurement. Clin Biochem 2007; 40: 1291-96.

7 ) Miida T, Nishimura K, Okamura T, et al: A multicenter study on the precision and accuracy of homogeneous assays for LDL-cholesterol: Comparison with a betaquantification method using fresh serum obtained from non-diseased and diseased subjects. Atherosclerosis 2012; 225: 208-15.

8 ) Miida T, Nishimura K, Hirayama S, et al: Homogeneous Assays for LDL-C and HDL-C are Reliable in Both the Postprandial and Fasting State. J Atheroscler Thromb 2017; 24: 583-99.

9 ) Yoshida H: Determination of Fasting and Non-Fasting Cholesterol Levels of Low- and High-Density Lipoproteins with Homogenous Assays: A Promising Reliable Way to Assessment of Dyslipidemia. J Atheroscler Thromb 2017; 24: 569-71.

10) Miida $T$, Nishimura K, Okamura $T$, et al: Validation of homogeneous assays for HDL-cholesterol using fresh samples from healthy and diseased subjects. Atherosclerosis 2014; 233: 253-9.

11) Mabuchi H, Koizumi J, Shimizu M, et al: Development of coronary heart disease in familial hypercholesterolemia. Circulation 1989; 79: 225-32.

12) Nordestgaard BG, Chapman MJ, Humphries SE, et al: Familical hypercholesterolaemia is underdiagnosed and undertreated in the general population: guidance for clinical to prevent coronary heart disease: consensus 


\section{総合健診における脂質異常症診療}

statement of the European Atherosclerosis Society. Eur Heart J 2013; 34: 3478-90.

13）日本動脈硬化学会：第 5 章 家族性高コレステロール血 症. 動脈硬化性疾患予防ガイドライン 2017 年版, 東京, 協和企画, $2017 ; 120-1$.

14）日本動脈硬化学会：参考資料 5 アキレス腱 $X$ 線撮影 方法. 動脈硬化性疾患予防ガイドライン 2017 年版, 東
京, 協和企画, 2017; 146.

15) Harada-Shiba M, Arai H, Okamura T, et al: Multicenter Study to Determine the Diagnosis Criteria of Heterozygous Familial Hypercholesterolemia in Japan. J Atheroscler Thromb 2012; 19: 1019-26.

16）馬渕 宏：セクションVI-1家族性高コレステロール血 症. 高脂血症入門, 東京, 文光堂, 2005: 54-5. 